\title{
Estates and Constitution: The Parliament in Eighteenth-Century Hungary. By István M. Szijártó. Translated by David Robert Evans. New York-Oxford: Berghahn, 2020. 350 pp.
}

Readers interested in the history of Austria, the Habsburg Monarchy, and its successor states may have become accustomed to the high academic quality of the series Austrian and Habsburg Studies (edited by Howard Louthan and published by Berghahn Books in association with the Center for Austrian Studies, University of Minnesota), which covers a wide range of themes in fields from ethnic conflict and nationalism to fin-de-siècle culture and women's history, to mention only a few of the subjects which have been covered since 1996, the year in which the first book in the series was published. István M. Szijártó's new book (the 30th title in the series) fits perfectly in this trend both because of its subject and by virtue of its complexity and rigorousness. Szijártó's outstanding monograph offers an admirable example of a work of scholarship on complex problems in the somewhat "exotic" history of early modern East Central Europe which both conforms to the local (in this case, the Hungarian) historiographical tradition and meets the standards of the Anglophone academic world. In the case of the latter, credit is also due to the excellent work of the translator, David Robert Evans.

Szijártó's endeavor is unique in the sense that he attempts to bring close to non-Hungarian readers the history of the Hungarian Diet, a topic which has been "grievously neglected in international scholarship," to use the words of Robert John Weston Evans from the back cover of the book. This is not to say, however, that the subject has been entirely ignored in recent non-Hungarian historiography. One could mention, perhaps first and foremost, the monograph by Jean Bérenger and Károly Kecskeméti, Parlement et vie Parlementaire en Hongrie 1608-1918 (Paris, Honoré Champion Editeur, 2005). Yet Estates and Constitution offers more than a work written in the traditional vein of parliamentary history in its narrower sense. To support this statement, it is worth taking a look at Szijártó's earlier works in the field to understand their evolution and determine their places in relation to one another. This is all the more important, since Szijártó himself felt it necessary to point out at the beginning of his work that his book is "the product of almost three decades of research" (xi).

The first significant fruit of Szijártó’s long-term research project was his 2005 monograph $A$ diéta. A magyar rendek és az országgyülés, 1708-1792 [The Diet. The Hungarian estates and the parliament, 1708-1792] (Budapest, Osiris), which 
became the fundamental work in the field. Although attention was paid to the social historical background (first and foremost to the fundamental role of the bene possessionatus nobility, the prosperous landowning gentry in the counties, and, later, the Diets) both in this monograph and in Szijártó's subsequent collection of studies, entitled Nemesi társadalom és politika: Tanulmányok a 18. száaadi magyar rendiségról [Noble society and politics: Studies on the history of the estates in eighteenth-century Hungary] (Budapest, Universitas, 2006), in his later works, Szijártó offered more thorough and nuanced discussions of the social-historical aspects of institutional change. In his 2016 book A 18. századi Magyarország rendi országgyülése [The Diet in eighteenth-century Hungary] (Budapest, Országgyülés Hivatala) and in his 2017 DSc thesis Emberek és struktúrák a 18. sqázadi Magyarorsұágon: A politikai elit társadalom-és kultuirtörténeti megközelitésben [Individuals and structures in eighteenth-century Hungary: The political elite from the perspective of social and cultural history], he provided a thorough analysis of the roles of the bene possessionatus nobility and the career paths of political actors. However, in these works, the change of perspective became manifest on another level, namely in Szijártó's growing interest in questions concerning cultural history and the history of political discourse. In fact, these latter aspects come to the fore in Estates and Constitution, too, which is a "modified, extended, and restructured" version of Szijártó's abovementioned 2016 book in Hungarian (p.xi). In a sense, Szijártó's recent monograph in English can be seen as a concise account of the main findings of this long-term research project, adjusted to the extent necessary to specific circumstances arising from the situation when a scholar aims to speak to a "global" audience about historical problems rooted in chiefly "local" contexts.

The structure of the book is quite user-friendly, and although its primary character is that of a monograph, it could also be used as a handbook. It has been broken into three sections, each of which is divided into chapters, which again have several subsections, most of them a few pages long. Broadly speaking, each of the main parts covers a fundamental aspect of eighteenth-century politics and is written from a specific analytical viewpoint. In the first part (Chapters 1-2), the principal structural elements of early modern Hungarian politics and the machinery of the Diet are outlined; in the second (Chapters 3-7), the parliament is presented as a functioning institution and the main locus of political practice; in the third (Chapters 8-10), some aspects of the political discourse and socialcultural history are in the foreground, alongside the historiography of the early modern parliament. 
One of the main strengths of the book is its primarily holistic outlook. Szijártó presents institutional, social-cultural, and intellectual issues as different aspects of one and the same history. If one reads the analyses carefully, one gets a detailed picture of their complex interrelations, at least in the context of the eighteenth-century parliamentary history of Hungary. In addition, Szijártó's essentially holistic approach goes hand in hand with his highly sensitive insights into grassroots level phenomena. Big processes and large structures are handled in close relation to the dimension of human agency and everyday practices of parliamentary life, and individual occurrences are never treated as mere illustrations of general tendencies. This feature of the book seems to be all the more important, since the mutual interdependence of these two dimensions becomes manifest on various levels throughout the analyses. Accordingly, the most common narrative structure of the subsections is a sequence consisting of a general account of the overall trends, followed by a thorough analysis of the most relevant cases supporting, nuancing, or modifying the original statements. Of course, this manner of writing history is only possible on the basis of a vast corpus of historical sources, and indeed this can be seen as the backbone of the whole work.

Chapter 1 provides a summary of the most crucial elements of eighteenthcentury Hungary's political system. Szijártó pays particular attention here to the dualism of king and estates, which made eighteenth-century Hungary an estate polity (Ständestaat), and he emphasizes the paramount importance of the tractatus diaetalis, the process of negotiation between the two sides of the political chessboard (pp.12-17). The long-term functioning of the Diet as the main locus of the bargaining process between king and estates demonstrates that the power of the latter proved much more durable in Hungary than in other parts of the empire, since the Habsburgs felt it necessary to convoke the Diet in the country "even after a hiatus of five, ten, or even twenty-five years" (p.18). The historical fundament of the Hungarian Sondervveg, as Szijártó stresses several times in the book, was the Rákóczi War of Independence and the compromise between crown and country which came in its wake, codified in the Treaty of Szatmár, which "stabilized the position of the Hungarian estates, restoring the dualism of king and estates of the previous era" (pp.2, 98-99). The significance of the separate path taken by Hungary became manifest during the War of the Austrian Succession, in the course of which the Hungarian estates remained loyal to Vienna and, as a result, Hungary (unlike the Hereditary Lands and the Czech provinces) was left out of the centralizing and rationalizing reforms of 
Haugwitz, which "represented a turning point in the political development of the Habsburg Monarchy" (p.99).

After portraying the main institutional factors of the workings of the Diet in Chapter 2, Szijártó goes on to outline one of the main findings of his book, and he demonstrates that in the eighteenth century, a profound change took place in the political agenda of the parliament, leading from confessionalism to the emergence of the dualism of king and estates dominated by constitutional questions. Religious issues, after dominating the debates in the 1710s and the 1720s, were (at least until 1790) omitted from the discussions of the Diets. Denominational divisions lost their former importance, and the defense of different aspects of noble privileges came to the foreground in parliamentary politics. As the investigations in Chapter 4 show, this process made it possible for the estates to take a strong line against the ruler in questions concerning the size of the yearly contribution (contributio) and the nobility's exemption from taxation. The new situation induced the decrease of the level of polarization within the estates and gave rise to a new form of antagonism vis-à-vis the crown, narrowing the possibility of compromise between king and estates considerably. In Chapter 6, this sharpening of divisions between crown and country is also demonstrated on the level of the political decisions of the deputies, displaying the process in the course of which "oppositionality and government loyalty" became "mutually exclusive choices" (p.171).

The main social-historical component of this process was the emancipation of the well-to-do gentry, the bene possessionatus nobility from the aristocracy, which came to dominate the political life of the counties in the course of the first half of eighteenth century. In the background of this process, which is described in Chapter 9, we find the dissolution of the old networks of familiaritas between the aristocracy and the lesser nobility and the takeover of the power of the landowning prosperous gentry in the counties. The breaking up of the system of patron-client relations resulted in a significantly higher degree of social and political independence of the bene possessionatus nobility. On the institutional level, the growing significance of the well-to-do gentry manifested itself at first at the county assemblies, where it became the leading political force.

However, several aspects of the institutional development of the Diet in the eighteenth century (most importantly the decision-making mechanisms and the increase of the importance of the county deputies, as shown in Chapter 7) make it clear that the bene possessionatus nobility was able to reassert itself on the level of parliamentary politics as the predominant political factor. Undoubtedly, 
the "noble-national" movement in Hungary in 1790 was part of this process: in fact, it can be seen as an attempt by the well-to-do gentry to reshape the political system of the country according to its own interests and values, aiming to convert its local dominance in the counties to real political power on the "national" level.

At this point, the relevance of the perspective of intellectual history, from which Chapter 8 is written, becomes clear. Through textual analyses of various sources, Szijártó verifies his thesis concerning polarization between king and estates as the "central tendency of politics" (p.263) on the level of political discourse as well. Szijártó demonstrates inter alia the rise of the term "constitution" in the political parlance of the Diets, a process that can be seen as a main element of the conceptual foundations of nineteenth-century developments in political discourse and in the politics of grievance in general.

Henrik Hőnich University of Public Service, Thomas Molnar Institute for Advanced Studies honichhenrik@gmail.com 